\title{
Developmental variability in the poecilogonous opisthobranch Haminaea callidegenita: life-history traits and effects of environmental parameters
}

\author{
Glenys D. Gibson*, Fu-Shiang Chia** \\ University of Alberta, Department of Zoology, Edmonton, Alberta, Canada T6G 2E9
}

\begin{abstract}
The opisthobranch Haminaed callidegenita has poecilogonous development (i.e. produces more than 1 type of offspring) based on swimming ability, and therefore dispersal potential, of offspring. Both swimming veligers (non-feeding) and crawling juveniles were simultaneously released from almost every egg mass (EM) $(97 \%)$ indicating that development mode varied among the offspring of single individuals as well as throughout the population. Development of all offspring per EM appeared to be identical until just prior to hatching when approximately half of the siblings metamorphosed and hatched as juveniles. The remaining siblings hatched as veligers and metamorphosed after a planktonic period ranging from 1 to $30 \mathrm{~d}$. Variable hatching appears to be typical in this species because it occurs in almost every EM, is independent of some environmental variables, and many hatched veligers have a relatively long planktonic perıod before becoming competent. The percentage of juvenile hatchlings was highly variable among EM (ranging from 4 to $100 \%$ ). Variability in hatchling type occurred among clutches, populations, and years. Also, hatchling type was influenced by a 'poor' parental environment in that food deprived females initially produced more swimming larvae than did control females. The percentage of juveniles released per EM was otherwise conservative in that it was not influenced by many of the other factors tested including: physical EM characteristics, female reproductive traits (fecundity, female size, egg size), time of year, source of metamorphic inducer and culture conditions.
\end{abstract}

KEY WORDS: Poecilogony $\cdot$ Developmental variability $\cdot$ Larval ecology Opisthobranch

\section{INTRODUCTION}

Poecilogony is an unusual life-history pattern involving the production of more than 1 type of offspring within a single species (Giard 1905). Species with variable development attract interest because poecilogony may provide a species with multiple advantages generally attributed to individual life-history patterns. Also, mechanisms that underly a potential shift in development mode may give insight to a greater

Present addresses:

- Marine Life Research Group, Scripps Institution of Oceanography, University of California, San Diego, La Jolla, California 92093-0218, USA

"Hong Kong Institute of Science and Technology, Clear Water Bay, Kowloon, Hong Kong understanding of life-history evolution without invoking difficulties inherent to inter-species comparisons. Giard (1905) listed dozens of examples in several phyla. Most of his examples, and those of subsequent authors, have been disproven as observations were made on sibling species or reflected atypical development resulting from laboratory or collection conditions (see reviews by Hoagland \& Robertson 1988, Bouchet 1989). The few cases in which poecilogony has not been disproven remain controversial primarily because they occur in the opisthobranch molluscs and polychaete annelids. As both groups are difficult taxonomic subjects, the validity of these cases have been questioned.

Observation of poecilogony should confirm that only a single species is involved and that development varies naturally rather than as an artifact. Description 
of poecilogony within 1 species involves either observation of variable development among the offspring of a single individual (Gibson \& Chia 1989b), or crossbreeding experiments in cases where development differs among offspring of individuals (Levin et al. 1991), including evidence that selfing did not occur. Laboratory conditions are believed to underly many proposed cases of poecilogony in which most offspring hatch as juveniles and a few early hatchlings are released as lecithotrophic larvae which metamorphose within hours of hatching (e.g. Gohar \& Eisawy 1967, Schmekel \& Kress 1977); these species may otherwise exhibit benthic development (Hoagland \& Robertson 1988). Observations of poecilogony should include experimental manipulation of culture conditions to exclude such artifacts. Evidence that poecilogony is widespread in natural populations suggests that it is the typical reproductive mode for that species, and perhaps more importantly, also illustrates its ecological relevance to the species.

The cephalaspidean opisthobranch Haminaea callidegenita (Gibson \& Chia, 1989a) (Haminaea = Haminoea, cf. Giannuzzi-Savelli \& Gentry 1990) presents an unusual case in which poecilogony occurs in almost every egg mass (EM). Therefore, it occurs in the offspring of single individuals as well as throughout the population. In this species, both lecithotrophic (nonfeeding) veliger larvae and crawling juveniles hatch from a single EM (Gibson \& Chia 1989b). The ecological result is that each parent produces offspring with a relatively high dispersal potential as well as offspring that may recruit immediately into the parental population. Development of all offspring appears to be identical throughout the $15 \mathrm{~d}$ encapsulated period until about $24 \mathrm{~h}$ before hatching begins. Approximately half the siblings per EM metamorphose within the EM and hatch as juveniles, and the other half hatch as veligers and metamorphose after a planktonic period ranging from 1 to $30 \mathrm{~d}$. Both types of hatchling are released throughout the entire hatching period (ranging from 1 to $12 \mathrm{~d}$ ). Metamorphosis within the EM is induced by a compound found in the jelly matrix covering the eggs (Gibson \& Chia 1989b, 1994). The degree of intracapsular metamorphosis varies widely (ranging from 4 to $100 \%$ ), but poecilogony was observed in almost every EM $(97 \%)$.

In this paper, we examine poecilogony in Haminaea callidegenita and mechanisms that may influence rates of intracapsular metamorphosis, and therefore the percentage of juveniles released per EM. Results indicate that the percentage of juvenile hatchlings per mass varied among clutches, among populations, and among years. Also, the percentage of offspring hatching as juveniles decreased in a short term response to a stressful parental environment. We think that vari- ability in hatchling type is typical for this species because it occurs independently of laboratory culture conditions and because of the relatively long planktonic period of some hatched veligers.

\section{MATERIALS AND METHODS}

Animal collection and culture. Haminaea callidegenita adults and egg masses (EM) were collected from Padilla Bay, Washington, USA, (48 $\left.30^{\circ} \mathrm{N}, 122^{\circ} 29^{\prime} \mathrm{W}\right)$ and maintained at the University of Washington Friday Harbor Laboratory, Washington, USA (Fig. 1). Padilla Bay is part of a large estuarine system and is dominated by extensive mud flats and seagrass beds containing both Zostera marina and Zostera japonica. H. callidegenita are primarily found in association with Zostera blades, surface sediments around Zostera roots, and mats of Ulva sp. in the upper intertidal zone.

Haminaea callidegenita were collected at different stages in the 3 years of this study. In 1990, adults were collected at the beginning of the spawning season (April), as determined by the first appearance of EM. Data for 1991 and 1992 included specimens collected as juveniles ( $<8 \mathrm{~mm}$ in length) in the autumn of the previous year and raised to maturity in the laboratory. These were used in a half-sib genetic analysis of poecilogony, and culture conditions are further described elsewhere (Gibson 1993). Data from all 3 years are considered in this paper as mean expressions of each trait per year are similar, despite differences in duration of laboratory culture ( 5 vs $10 \mathrm{mo}$ ) and paternity of offspring (mixed in 1990, single in 1991 \& 1992). Adults were maintained in the laboratory in 11 'Tripour'

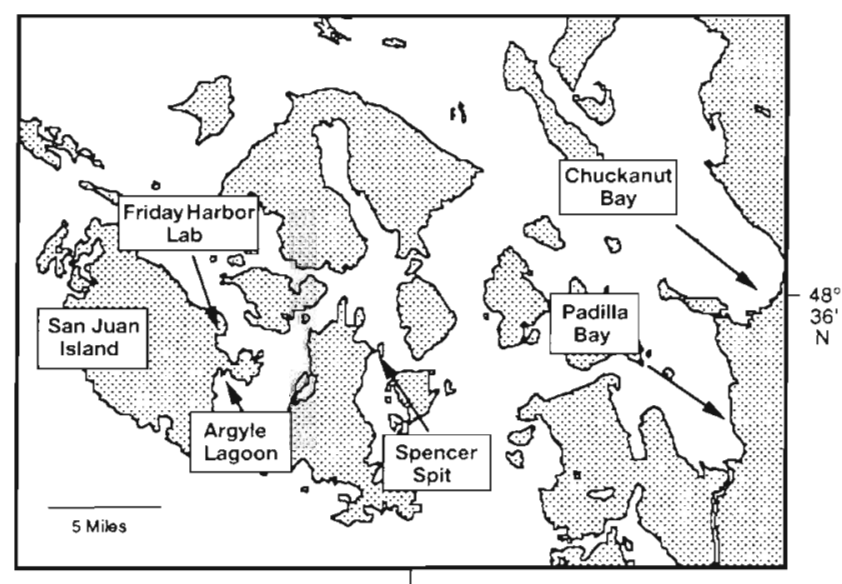

$122^{\circ} 49^{\prime} W$

Fig. 1. Haminaea callidegenita were collected in Padilla Bay, Chuckanut Bay and Spencer Spit in Washington State, USA Slugs were maintained at the University of Washington Friday Harbor Laboratory 
beakers with Nitex mesh vents that allowed continuous seawater flow at ambient conditions. Food was Ulva sp. attached to rocks collected intertidally at Friday Harbor Laboratory and both Ulva and rock provided a substrate from which Haminaea grazed diatoms, detritus and UIva pieces.

EM were cultured in $50 \mathrm{ml}$ of $1 \mu \mathrm{m}$ filtered seawater at $17^{\circ} \mathrm{C}$. Warm temperatures correspond to ambient conditions in Padilla Bay, which is generally warmer (mean of $16.5^{\circ} \mathrm{C}$ from June to August; Cassidy \& Mckeen 1986) than nearby channels (summer mean of $11.3^{\circ} \mathrm{C}$ ). Culture water was replaced twice weekly.

Experimental procedures. Reproductive traits of 181 females were measured in the laboratory (104 in 1990, 44 in 1991, 33 in 1992). These females produced a total of 840 EM. As the major character of interest was the percentage of siblings per EM to undergo intracapsular metamorphosis the relationship of each trait with the percentage of juveniles hatching from each EM (arcsin transformed) was estimated by Model I Regression (Sokal \& Rohlf 1981, LaBarbera 1989). For most laboratory manipulations, EM were collected from Padilla Bay. Masses used were collected at the gastrula stage in attempts to synchronize masses for time of oviposition.

Embryonic and larval development. Development was examined from oviposition to metamorphosis. Length of the encapsulated period was determined as the number of days from oviposition to the onset of hatching. Length of the hatching period was the number of days from the onset to completion of hatching. Hatching involved the larva or juvenile rupturing the embryonic capsule with its foot and crawling out of the gelatinous matrix which covers the capsules and composes most of the EM.

Time of metamorphosis was determined for both the pre-hatching and post-hatching periods. The percentage of juvenile hatchlings (i.e. the proportion of siblings per clutch that became competent and metamorphosed within the EM) was determined by removing hatchlings daily throughout the hatching period and immediately scoring them as veligers or juveniles under a Wild M-5 microscope. Veligers were identified by the presence of an intact velum and were either swimming or, less frequently, crawling when counted. Individuals which had lost velar cilia and in which the velar lobes were resorbed were scored as juveniles. In most cephalaspideans, the shell is retained throughout the adult stage. Estimates of time of metamorphosis may have been inflated by the metamorphosis of hatched veligers within the $24 \mathrm{~h}$ intervals between counts; however, this effect was judged to be slight as the mean time of the first metamorphosis per clutch after hatching was approximately $3 \mathrm{~d}$ post-hatching (this study). A clutch includes all siblings per EM.
Time of metamorphic competence after hatching was measured by culturing naturally hatched veligers continuously in the presence of metamorphic inducer (egg mass jelly, EMJ; Gibson \& Chia 1989b). Juveniles were counted and removed at $24 \mathrm{~h}$ intervals. Up to 30 hatched veligers were tested per EM, depending on the number available. Veligers were placed in tissue culture wells containing $1 \mathrm{ml}$ of $1 \mu \mathrm{m}$ filtered seawater and approximately $1 \mathrm{~mm}^{3} \mathrm{EMJ}$, with up to 5 veligers in each well. Culture water and jelly were replaced twice weekly. The planktonic period was separated into the minimum planktonic period (time of the first metamorphosis of a hatched veliger) and the maximum time of competence per clutch (time of completion of metamorphosis by all siblings per clutch).

Hatched veligers were found to undergo a delayed, spontaneous metamorphosis (i.e. occurring without an apparent inducer; Highsmith \& Emlet 1986). The ability of larvae to delay metamorphosis was determined by culturing hatched veligers as above but in the absence of metamorphic inducer. Seawater was filtered and sterilized (microwaved at high power for $3 \mathrm{~min}$, water boiling for at least $1 \mathrm{~min}$ ) to prevent contamination from bacteria and diatoms and the possible inadvertent induction of metamorphosis by other sources (Gibson 1993). The planktonic period was separated into minimum ability to delay (time of the first delayed metamorphosis of a hatched veliger per clutch) and maximum planktonic period (maximum time metamorphosis could be delayed per clutch) as outlined above for time of competence. Cultures were maintained until all larvae per clutch had metamorphosed.

Female reproductive traits. Reproductive traits included estimates of size and fecundity. Size was estimated as the blotted wet weight (mg) of females at the beginning of the reproductive period. Fecundity estimates included (1) clutch size, or the number of offspring hatched per EM (embryo mortality was extremely low); (2) mean egg size (maximum dimension) per female; (3) spawning interval, or the number of days between spawning events per female, and (4) the total number of eggs and EM produced per female throughout the spawning season. Data were analyzed with a 1-way Analysis of Variance (ANOVA) to test for differences in egg size among females. Linear regression was used to test for a relationship between the mean egg size per female and characteristics of her offspring, such as the mean percentage of juvenile hatchlings or the mean time of metamorphosis of hatched veligers. As differences in egg size were small within Haminaea callidegenita EM (Gibson pers. obs.), the fate of individual eggs was not examined.

Seasonal variation. Seasonal changes in rates of intracapsular metamorphosis were assessed in the 
laboratory and in the Padilla Bay population. In the laboratory, individual changes were examined by comparing sequentially produced EM throughout the reproductive period for isolated Haminaea callidegenita (approximately a 2 mo period, life span approximately 1 yr; Gibson \& Chia 1991). Seasonal changes in the field were assessed by collecting EM from Padilla Bay at monthly intervals (1990 \& 1991, 20 EM per month, all collected at the gastrula stage) throughout the period of peak spawning (May to October).

Culture conditions. The effects of culture temperature on the percentage of juveniles hatching per EM were tested by culturing 10 masses at 9,15 and $21^{\circ} \mathrm{C}$. Embryos were maintained from the gastrula stage to completion of hatching.

EM were cultured in standing or flowing seawater in the laboratory and in the field. In laboratory assays, EM were divided into 2 groups ( $\mathrm{n}=12 \mathrm{EM}$ for each group) and cultured at ambient seawater conditions $\left(11\right.$ to $12^{\circ} \mathrm{C}$ ). Group 1 (flowing seawater) was cultured in ice cube trays in which the bottom of each chamber was replaced with $100 \mu \mathrm{m}$ Nitex mesh (1 EM per chamber). Filtered seawater continuously flowed down through the chambers at approximately $20 \mathrm{ml} \mathrm{min}^{-1}$ chamber. Group 2 (standing seawater) were cultured in $50 \mathrm{ml}$ of $1 \mu \mathrm{m}$ filtered seawater (1 EM per jar) in standing cultures as a control.

EM cultured in the field were placed in plastic snapcap vials (ca $50 \mathrm{ml}$ volume) that were either (1) intact, for 'standing seawater' conditions, or (2) supplied with $2100 \mu \mathrm{m}$ Nitex mesh vents (each $2 \mathrm{~cm}^{2}$ in area) to allow continual seawater flow through the vial $(\mathrm{n}=10$ EM for each group). Vials were attached to the inside of a Plexiglas rack and the rack covered with an open mesh $\left(5 \mathrm{~cm}^{2}\right.$ holes) to prevent clogging of the vials by floating macroalgae and diatom rafts. The rack was suspended in Argyle Lagoon (Fig, 1), which is a sheltered, shallow lagoon with summer temperatures similar to those found in Padilla Bay. Argyle Lagoon contains a seagrass community that is similar to Padilla Bay but does not drain at low tide, preventing desiccation of the EM.

In both of these experiments, culture chambers were cleaned daily to ensure seawater flow. Hatchlings were removed daily throughout the hatching period and immediately scored as veligers or juveniles. Data were compared between culture treatments with an unpaired 2-tailed $t$-test for each experiment (field or laboratory). Data from 1991 (field) were also compared with EM cultured using the standard laboratory protocol (standing cultures in an incubator; described above).

Parental environment. Adult Haminaea callidegenita were maintained on 1 of 2 feeding regimes: Group 1 (full rations, $n=8$ adults) had excess food available continuously throughout a $40 \mathrm{~d}$ period, and Group 2 (half rations, $\mathrm{n}=18$ adults) had food provided for $24 \mathrm{~h}$ alternating with food deprivation for $24 \mathrm{~h}$ throughout the experimental period. Food was Ulva attached to rocks as described above. When food was removed, the cages were scrubbed with freshwater to remove accumulated diatoms and bacteria. Cages were then re-submerged in flowing, unfiltered seawater that did allow water-borne diatoms and bacteria to enter the cage. A deprivation interval of $24 \mathrm{~h}$ was considered adequate because individuals left without food for 3 to $4 \mathrm{~d}$ became completely inactive. Therefore, even though food was not completely excluded during this experiment, specimens were considered to be energetically stressed. Number of hatchlings, length of the hatching period, and the percentage of juvenile hatchlings were determined for each EM.

Comparison among populations. EM were collected on 8 June 1992 from 3 sites: Padilla Bay, Chuckanut Bay, and Spencer Spit (Fig. 1). Chuckanut Bay is part of the same major estuarine system as Padilla Bay and is located approximately $21 \mathrm{~km}$ from the Padilla Bay site. It is similar to Padilla Bay in that it is composed of a large mudflat dominated by Zostera marina and $Z$. japonica. Spencer Spit is the more distant site (approximately $32 \mathrm{~km}$ from Padilla Bay). It is a shallow, isolated lagoon with restricted access to open water, and never exposed at low tide. Dominant flora are UIVa sp. and mats of the filamentous green alga Chaetomorpha linum. As clutch size is known to affect other traits of the EM (this study), we attempted to select EM that were approximately the same size, although we were restricted at Spencer Spit to large masses as smaller masses were not available. In the laboratory, 20 EM per site were chosen based on developmental stage (those selected had not yet undergone the second cleavage) in attempts to use masses synchronized in terms of time of spawning. Number of hatchlings, length of the hatching period, and the percentage of juvenile hatchlings per EM were determined.

Source of metamorphic inducer. EMJ is known to induce intracapsular metamorphosis in Haminaea callidegenita (Gibson \& Chia 1989b, in press). The relative effects of the embryos within an EM vs EMJ in determining rates of intracapsular metamorphosis were compared in a random block design with 1 block per cell. Gastrulae were separated from each EM and subsampled into 6 groups of 20 embryos each. Each subsample was treated with EMJ separated from 1 of 6 additional EM in the design outlined in Table 5A. In this design, each subsample of embryos per clutch was treated with EMJ from a different source. Data were analyzed with a 2 way ANOVA. 


\section{RESULTS}

\section{Description of poecilogony in Haminaea callidegenita}

Haminaea callidegenita produce both veligers and juveniles from almost every EM. The mean percentage of juveniles released at hatching was 57,85 and $90 \%(1990,1991$ and 1992 respectively; Table 1), ranging from 4 to $100 \%$ juveniles overall. Approximately $3 \%$ of the EM observed released juveniles only. Every female produced both types of offspring throughout most of her reproductive period.
Most experiments in this paper were designed to test factors that potentially influence the extreme variance in the percentage of juvenile hatchlings (i.e. the rate of intracapsular metamorphosis). Two additional estimates of metamorphosis were also considered: time of metamorphic competence after hatching, indicated by metamorphosis of hatched veligers cultured in the presence of a metamorphic inducer (EMJ), and the ability of hatched larvae to delay metamorphosis if an inducer was withheld. Hatched veligers became competent to metamorphose between 1 to $30 \mathrm{~d}$ after hatching (Table 1, Fig. 2). The mean time of onset of competence was $3.7 \mathrm{~d}$ after hatching, and metamorphosis was

Table 1. Haminaea callidegenita. Development rates. (A) Means ( \pm SE) and results of an ANOVA comparing data from 3 years. (B) Result5 of a Model I regression of development rates $(x)$ on the percentage of offspring released as juveniles ( $y$ ), or of intraclutch rates of metamorphosis as the percentage of juvenile hatchlings $(x)$ on rates of metamorphosis after hatching $(y)$ for each egg mass (EM). nc: data not collected. $n$ : number of clutches (=EM). $\cdots p<0.001, \cdots p<0.01$; ns: not significant

\begin{tabular}{|c|c|c|c|c|c|c|c|c|c|}
\hline \multicolumn{10}{|l|}{ (A) Trait summary } \\
\hline \multirow[t]{2}{*}{ Trait } & \multicolumn{2}{|c|}{1990} & \multicolumn{2}{|l|}{1991} & \multicolumn{2}{|c|}{1992} & \multirow[t]{2}{*}{ Min } & \multirow[t]{2}{*}{ Max } & \multirow[t]{2}{*}{ Year differences } \\
\hline & $\bar{x}$ & n & $\bar{x}$ & $\mathrm{n}$ & $\bar{x}$ & $\mathrm{n}$ & & & \\
\hline Encapsulated period (d) & $15.3 \pm 0.1$ & 211 & $14.4 \pm 0.1$ & 234 & $14.4 \pm 0.1$ & 235 & 9 & 21 & $F_{2,679}=25.71 \cdots$ \\
\hline Hatching period (d) & $4.6 \pm 0.1$ & 211 & $6.1 \pm 0.2$ & 234 & $3.8 \pm 0.1$ & 235 & 1 & 13 & $F_{2,679}=81.91 \cdots$ \\
\hline \multicolumn{10}{|l|}{ Metamorphic competence clutch ${ }^{-1}$} \\
\hline $\begin{array}{l}\text { (2) Metamorphosis post-hatchir } \\
1 \text { st metamorphosis (d) } \\
100 \% \text { metlamorphosed (d) }\end{array}$ & $\begin{array}{l}\text { nc } \\
\text { nc }\end{array}$ & & $\begin{array}{l}\mathrm{nc} \\
\mathrm{nc}\end{array}$ & & $\begin{aligned} 3.7 & \pm 0.1 \\
13.6 & \pm 0.5\end{aligned}$ & $\begin{array}{l}137 \\
137\end{array}$ & $\begin{array}{l}2 \\
2\end{array}$ & $\begin{array}{l}11 \\
30\end{array}$ & \\
\hline $\begin{array}{l}\text { (3) Ability to delay metamorpho } \\
\text { 1st metamorphosis (d) } \\
100 \% \text { metamorphosed (d) }\end{array}$ & $\begin{array}{l}\text { nc } \\
\text { nc }\end{array}$ & & nc & & $\begin{array}{r}4.8 \pm 0.3 \\
20.6 \pm 0.7\end{array}$ & $\begin{array}{l}123 \\
123\end{array}$ & $\begin{array}{l}1 \\
3\end{array}$ & $\begin{array}{l}26 \\
42\end{array}$ & \\
\hline \multicolumn{10}{|c|}{ (B) Effect on poecilogony (\% juvenile hatchlings) } \\
\hline Trait & 1990 & & 1991 & & 1992 & & \multicolumn{3}{|c|}{ Summary of effects } \\
\hline Encapsulated period (d) & $\begin{array}{c}y=3.15 x+2.29 \\
r^{2}=0.07 \\
F_{1.210}=15.47 \cdots\end{array}$ & & $\begin{array}{c}y=2.58 x+33.2 \\
r^{2}=0.10 \\
F_{1.233}=25.76 \cdots\end{array}$ & & $\begin{array}{c}- \\
F_{1,235}=3 \\
\mathrm{p}=0.0\end{array}$ & & & $\begin{array}{l}1 \text { with l } \\
\text { riods re }\end{array}$ & $\begin{array}{l}\text { nger encapsulated } \\
\text { lease more juveniles }\end{array}$ \\
\hline Hatching period (d) & $\begin{array}{c}y=-2.28 x+61.17 \\
r^{2}=0.07 \\
F_{1,210}=14.49 \cdots\end{array}$ & & $\begin{array}{c}y=0.78 x+65.5 \\
r^{2}=0.03 \\
F_{1,233}=6.17 \cdots\end{array}$ & & $\begin{array}{r}y=-1.63 x+ \\
r^{2}=0.0 \\
F_{1.235}=12\end{array}$ & $\begin{array}{l}80.47 \\
5 \\
82 \cdots\end{array}$ & & $\begin{array}{l}\text { lect of } 1 \\
\text { riod dif }\end{array}$ & $\begin{array}{l}\text { ngth of hatching } \\
\text { ers among years }\end{array}$ \\
\hline \multicolumn{10}{|l|}{$\begin{array}{l}\text { Metamorphic competence clutch-1 } \\
\text { (1) Metamorphosis post-hatching }\end{array}$} \\
\hline 1st metamorphosis (d) & $\mathrm{nc}$ & & nc & & \multicolumn{2}{|c|}{$\begin{array}{c}- \\
F_{1,136}=2.08 \mathrm{~ns}\end{array}$} & \multicolumn{3}{|c|}{ None } \\
\hline $100 \%$ metamorphosed (d) & $\mathrm{nc}$ & & nc & & \multicolumn{2}{|c|}{$\begin{array}{c}y=-0.25 x+31.96 \\
\mathrm{r}^{2}=0.12 \\
F_{1.136}=18.16 \cdots\end{array}$} & \multicolumn{3}{|c|}{$\begin{array}{l}\text { Clutches with high rates of } \\
\text { intracapsular metamorphosis } \\
\text { have a shorter overall meta- } \\
\text { morphic period }\end{array}$} \\
\hline $\begin{array}{l}\text { (3) Ability to delay metamorpho } \\
\text { 1st metamorphosis (d) }\end{array}$ & nc & & nc & & \multicolumn{2}{|c|}{$\begin{array}{c}y=0.10 x-2.54 \\
r^{2}=0.06 \\
F_{1.122}=7.78\end{array}$} & \multicolumn{3}{|c|}{$\begin{array}{l}\text { Initial ability to delay metamor- } \\
\text { phosis is greater in clutches } \\
\text { with high rates of intracapsular } \\
\text { metamorphosis }\end{array}$} \\
\hline $100 \%$ metamorphosed (d) & nc & & nc & & \multicolumn{2}{|c|}{$F_{1,122}=1.35 \mathrm{~ns}$} & \multicolumn{3}{|c|}{ None } \\
\hline
\end{tabular}




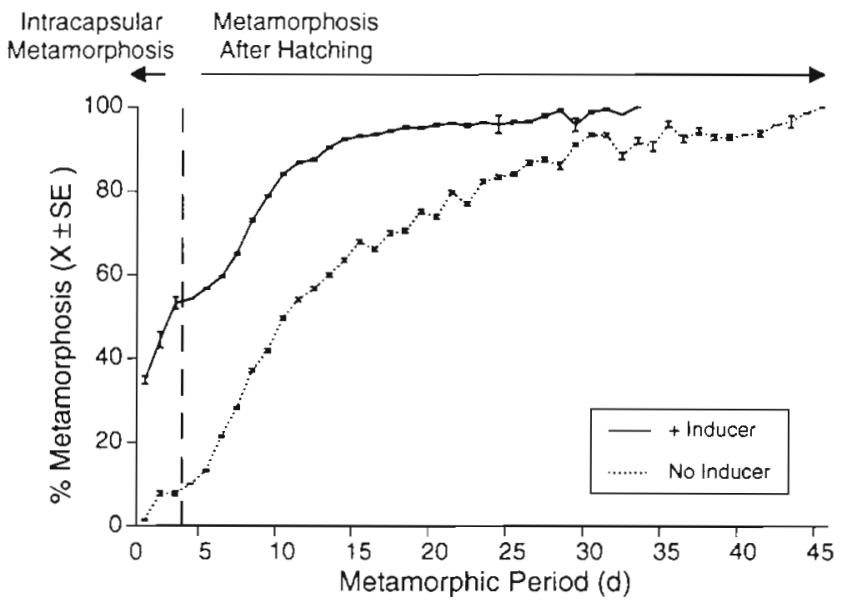

Fig. 2. Haminaea callidegenita. Rates of metamorphosis throughout the metamorphic period (both before and after hatching). Data are cumulative means ( \pm SE) for 137 clutches raised in the presence of metamorphic inducer (egg mass jelly; solid line) and 123 clutches raised in the absence of inducer (dotted line). The dashed line marks the end of the encapsulated period

completed by $13.7 \mathrm{~d}$ after hatching, as compared among clutches (Table 1, Fig. 2). Larvae also had a limited ability to delay metamorphosis if inducer was not supplied, both before and after hatching. Almost no metamorphosis occurred in encapsulated larvae cultured in seawater only; i.e. these offspring hatched from the capsule as veligers (Fig. 2, also see Gibson \& Chia 1989b). After hatching, the onset of metamorphosis was slightly but significantly delayed to $4.8 \mathrm{~d}$ after hatching (Table 1; results of a 2 -tailed $t$-test comparing time of the first metamorphosis after hatching with and without metamorphic inducer: $\mathrm{df}=256, t=-3.219, \mathrm{p}<$ $0.001)$. The time of completion of spontaneous metamorphosis within a clutch was also delayed to $20.6 \mathrm{~d}$ after hatching (results of a 2 -tailed $t$-test: $\mathrm{df}=256, t=$ $-7.48, \mathrm{p}<0.001)$. The maximum period of delay was $42 \mathrm{~d}$ post-hatching (Table 1, Fig. 2).

\section{Development rates}

The encapsulated period was approximately $15 \mathrm{~d}$ in duration (ranging from 9 to $21 \mathrm{~d}$ ), and showed slight differences among the 3 years examined (Table $1 \mathrm{~A}$, Fig. 3). In 2 years, EM with longer encapsulated periods released more juveniles, although the coefficients of determination were small $\left(r^{2} \leq 0.10\right.$; Table $1 B$. Fig. 3). The overall scatter in the percentage of juveniles hatching per EM was similar in most analyses to that observed in Fig. 3 and therefore presentation of most data involving reproductive traits will be limited to Tables 1 through 6 . Length of the hatching period was approximately $5 \mathrm{~d}$ (ranging from 1 to $12 \mathrm{~d}$ ) and also differed among years (Table $1 \mathrm{~A}$ ). The influence of length of hatching period on rates of intracapsular metamorphosis was not consistent throughout the study: EM with longer hatching periods either released fewer $(1990,1992)$ or more juveniles (1991), but the coefficients of determination were quite low.

Clutches with high rates of intracapsular metamorphosis (i.e. those releasing a high percentage of juveniles) also showed the fastest completion of metamorphosis of hatched siblings (Table 1B, Fig. 4A), resulting in a shorter overall metamorphic and therefore planktonic period. Clutches with high rates of intracapsular metamorphosis also released veligers with an increased ability to delay metamorphosis immediately after hatching although the time delayed metamorpho-

A. 1990

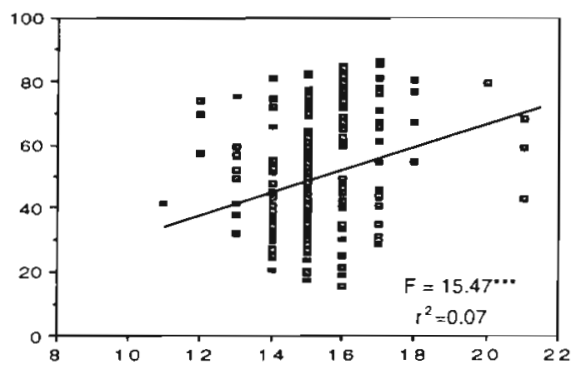

B. 1991

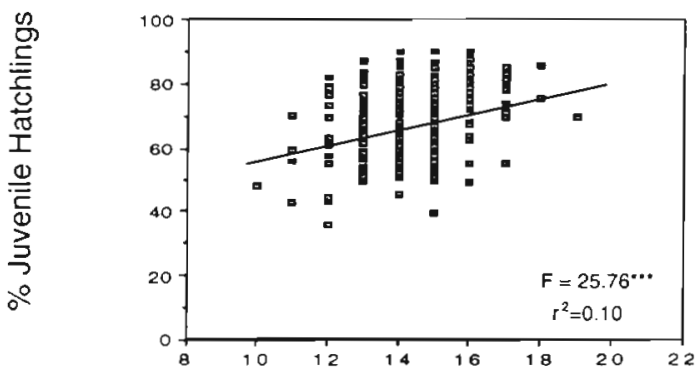

C. 1992

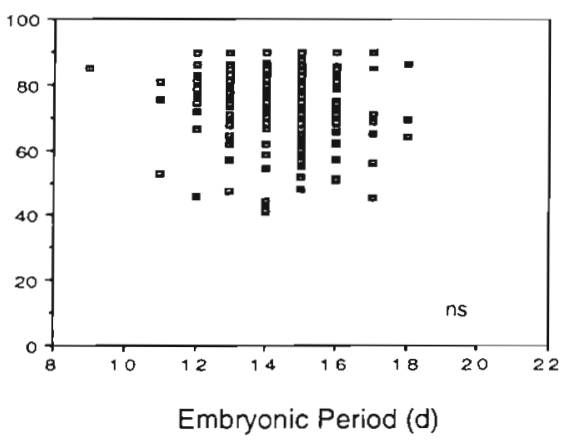

Fig. 3. Haminaea callidegenita. Effect of length of the encapsulated period on the percentage of juvenile hatchlings per EM, plotted with the results of a linear regression fof arcsin transformed data; see Table 1). Data from each year were analyzed separately. $\cdots p<0.001$; ns: not significant 


\section{A. Metamorphic Competence}

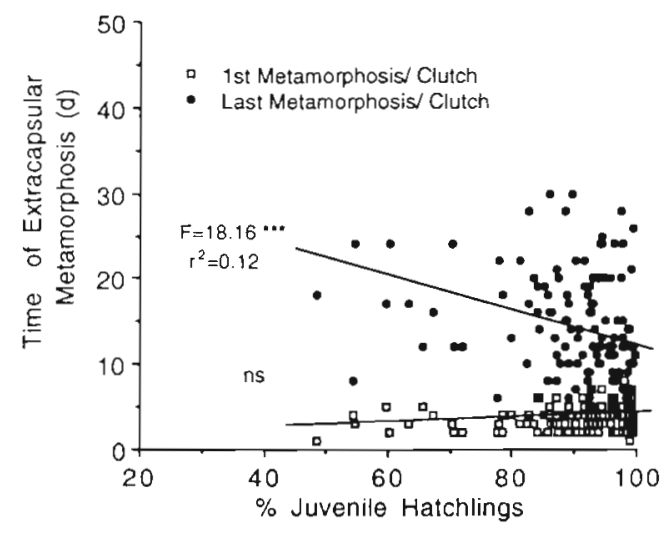

B. Ability to Delay Metamorphosis

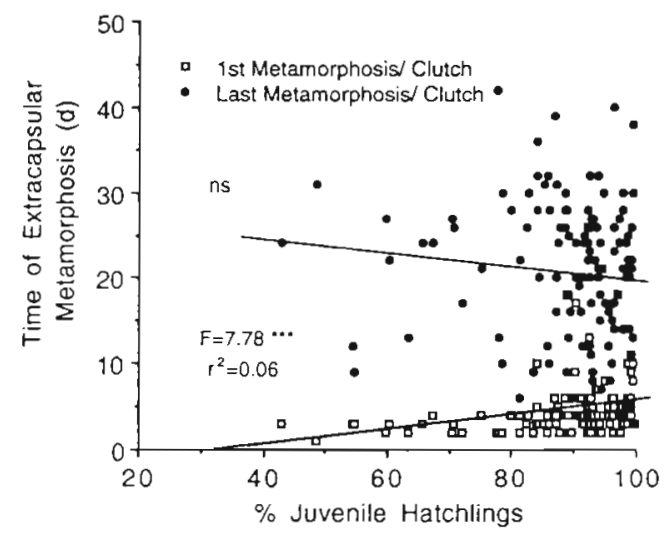

Fig. 4. Haminaea callidegenita. Comparison of rates of metamorphosis before and after hatching. (A) Results of a linear regression of the percentage of juvenile hatchlings farcsin transformed) on time of competence of siblings after hatching Time of competence was determined for the first hatched veliger per clutch (a) and for completion of metamorphosis by all siblıngs per clutch ( $\bullet$ ), determined using hatched veligers cultured in the presence of a metamorphic inducer (egg mass jelly; $n=137$ clutches). (B) Results of a linear regression of rates of intracapsular metamorphosis on ability of siblings to delay metamorphosis, determined as above for hatched veligers cultured in the absence of inducer ( $n=123$ clutches)

sis was completed per clutch (indicating the maximum possible planktonic period) was not affected (Table 1B, Fig. 4B).

\section{Female reproductive traits}

There were 4 traits considered: number of hatchlings per EM, interval between spawning events per female, total number of eggs per female, and number of EM per female. All 4 traits differed among years (Table 2A). Hatchling number per female was the only reproductive trait to show a significant relationship with rates of intracapsular metamorphosis. Fewer juve- niles were released from larger clutches (Table 2B). EM size (wet weight) had no effect (Table 2B) despite the fact that larger EM contained more eggs and wet weight accounted for a third of the observed variance in clutch size (Model I regression of effects of EM weight, $x$, on clutch size, $y$, for 1991: $\mathrm{df}=1,84 ; y=$ $\left.298.56 x+158.27 ; F=36.48, \mathrm{p}<0.001, \mathrm{r}^{2}=0.31\right)$.

\section{Female size}

Females were approximately $380 \pm 11 \mathrm{mg}$ at the beginning of the spawning period (ranging from 212 to $767 \mathrm{mg}$, or 13 to $26 \mathrm{~mm}$ in length). Linear regression was used to examine the effects of female size on traits of the first EM produced for all 3 years. Only the first EM was considered so differences in growth rates among females throughout the reproductive season would not confound the results. The only reproductive traits to be influenced by female size were clutch size and length of the hatching period. Both traits increased with female size but only in 1991 (Table 3). Female size did not influence time of metamorphic competence, either within the EM or after hatching (Table 3 ).

\section{Egg size}

Mean egg diameter was $262 \mu \mathrm{m}$ overall and differed significantly among females (Table $4 \mathrm{~A}$ ). There was no effect of mean egg size per female on the mean time of competence of her offspring (determined either as intracapsular metamorphosis or metamorphosis after hatching) or the ability of her offspring to delay metamorphosis (Table 4B).

\section{Source of metamorphic inducer}

In replicate experiments, embryos from different clutches had significantly different responses to the metamorphic inducer (Table 5) but inducer from different sources did not differ in inductive potential. Differences among clutches accounted for a substantial portion of the overall variance in both experiments $\left(r^{2}=0.49\right.$ and $r^{2}=0.87$ respectively). This indicated that the variance observed among EM in the percentage of juvenile hatchlings arises from the embryos and was independent of source of metamorphic inducer.

\section{Seasonal variation}

We examined variation in the expression of each trait throughout the spawning season of individual 
Table 2. Haminaea callidegenita. Summary of reproductive traits. (A) Means ( \pm SE) and results of an ANOVA comparing data from 3 years. (B) Results of a Model I regression of life history traits $(x)$ on the percentage of juveniles hatching from each egg mass $(y)$ nc: data not collected. $n$ : number of egg masses (EM) or number of females (for fecundity and number of EM). $\cdots p<0.001, \cdot p<0.05$; ns: not significant

\begin{tabular}{|c|c|c|c|c|c|c|c|c|}
\hline \multicolumn{9}{|l|}{ (A) Trait summary } \\
\hline \multirow[t]{2}{*}{ Trait } & \multicolumn{2}{|l|}{1990} & \multicolumn{2}{|l|}{1991} & \multicolumn{2}{|c|}{1992} & \multirow[t]{2}{*}{$\operatorname{Max}$} & \multirow[t]{2}{*}{ Year differences } \\
\hline & $\bar{x}$ & $\mathrm{n}$ & $\bar{x}$ & $n$ & $\widetilde{x}$ & $\mathrm{n}$ & & \\
\hline Egg mass size (mg) & $\mathrm{nc}$ & & $\mathrm{nc}$ & & $0.65 \pm 0.02$ & 88 & $0.31 \quad 1.65$ & \\
\hline No. hatched & $381.7 \pm 11.5$ & 210 & $374.5 \pm 9.8$ & 234 & $317.4 \pm 7.9$ & 236 & $27 \quad 907$ & $F_{2,679}=13.25 \cdots$ \\
\hline Spawn interval (d) & $6.3 \pm 0.4$ & 211 & $8.2 \pm 0.5$ & 234 & $4.9 \pm 0.3$ & 236 & 36 & $F_{2,680}=15.75 \cdots$ \\
\hline Fecundity (no. eggs fem. ${ }^{-1}$ ) & $1473 \pm 137$ & 83 & $2512 \pm 172$ & 35 & $2276 \pm 150$ & 33 & $46 \quad 6239$ & $F_{2,150}=12.88 \cdots$ \\
\hline No. of EM fem. ${ }^{-1}$ & $4.3 \pm 0.3$ & 83 & $6.7 \pm 0.4$ & 35 & $7.2 \pm 0.4$ & 33 & 11 & $F_{2,150}=24.59 \cdots$ \\
\hline \multicolumn{9}{|c|}{ (B) Effect on poecilogony ( $\%$ juvenile hatchlings) } \\
\hline Trait & 1990 & & \multicolumn{2}{|l|}{1991} & \multicolumn{2}{|l|}{1992} & \multicolumn{2}{|c|}{ Summary of effects } \\
\hline Egg mass size (mg) & nc & & nc & & $F_{1,84}=-\overline{0.06}$ & & \multicolumn{2}{|l|}{ None } \\
\hline Clutch size & \multicolumn{2}{|l|}{$\begin{array}{c}y=-0.02 x+56.45 \\
r^{2}=0.02 \\
F_{1.209}=4.90^{*}\end{array}$} & \multicolumn{2}{|l|}{$\begin{array}{c}- \\
F_{1,233}=2.55 \mathrm{~ns}\end{array}$} & \multicolumn{2}{|c|}{$\begin{array}{c}y=-0.02 x+81.39 \\
r^{2}=0.08 \\
F_{L, 235}=19.61 \cdots\end{array}$} & \multicolumn{2}{|c|}{$\begin{array}{l}\text { Fewer juveniles hatch from } \\
\text { larger clutches }\end{array}$} \\
\hline Spawn interval (d) & \multicolumn{2}{|l|}{$F_{1.210}=1.74 \mathrm{~ns}$} & \multicolumn{2}{|l|}{$\begin{array}{c}- \\
F_{1,233}=3.07 \mathrm{~ns}\end{array}$} & \multicolumn{2}{|c|}{$\begin{array}{c}- \\
F_{1,235}=3.78 \mathrm{~ns}\end{array}$} & \multicolumn{2}{|l|}{ None } \\
\hline Fecundity (no. eggs fem. ${ }^{-1}$ ) & \multicolumn{2}{|l|}{$F_{1,82}=\overline{0} .07 \mathrm{~ns}$} & \multicolumn{2}{|l|}{$F_{1,34}=\overline{0} .02 \mathrm{~ns}$} & \multicolumn{2}{|c|}{$F_{1,32}=-\overline{0.42 \mathrm{~ns}}$} & \multicolumn{2}{|l|}{ None } \\
\hline No. of EM fem ${ }^{-1}$ & \multicolumn{2}{|l|}{$F_{1,82}=-\overline{0.10 \mathrm{~ns}}$} & \multicolumn{2}{|l|}{$F_{1,34}=0.54 \mathrm{~ns}$} & \multicolumn{2}{|c|}{$F_{1,32}=1.76 \mathrm{~ns}$} & \multicolumn{2}{|l|}{ None } \\
\hline
\end{tabular}

Table 3. Haminaea callidegenita. Influence of female size on rates of development and clutch size. Data were collected for 3 groups of females $(1990,1991,1992)$. Results are from a linear regression of the effects of female size $(x)$ on each trait $(y)$. Data for each year were considered separately. Size is female wet weight $(\mathrm{mg})$ at the onset of the reproductive period. Only the first egg mass (EM) spawned by each female was considered in the analysis. Traits are defined in the text. nc: data not collected $\cdots p<0.001, \cdots p<0.01 ;$ ns: not significant

\begin{tabular}{|c|c|c|c|c|}
\hline Trait & 1990 & 1991 & 1992 & Summary of effects \\
\hline Encapsulated period (d) & $F_{1,41}=-1.90 \mathrm{~ns}$ & $F_{1,34}=\overline{0} .18 \mathrm{~ns}$ & $F_{1.31}=-\overline{0.82 \mathrm{~ns}}$ & None \\
\hline Hatching period (d) & $F_{1.41}=\overline{1.92 \mathrm{~ns}}$ & $\begin{array}{c}y=0.02 x-1.05 \\
r^{2}=0.47 \\
F_{1,34}=29.77 \cdots\end{array}$ & $F_{1,31}=1.59 \mathrm{~ns}$ & $\begin{array}{l}\text { Larger females may } \\
\text { produce EM that take } \\
\text { longer to hatch }\end{array}$ \\
\hline $\begin{array}{l}\text { Metamorphic competence clutch } \\
\text { (1) \% Juvenile hatchlings }\end{array}$ & $F_{1,41}=0.03 \mathrm{~ns}$ & $F_{1.34}=\overline{0} .29 \mathrm{~ns}$ & $F_{1.32}=\overline{0} .59 \mathrm{~ns}$ & None \\
\hline $\begin{array}{l}\text { (2) Time of metamorphosis post- } \\
\text { 1st metamorphosis (d) }\end{array}$ & $\begin{array}{l}\text { hatching (metam } \\
\text { nc }\end{array}$ & $\begin{array}{l}\text { phic inducer presen } \\
\text { nc }\end{array}$ & $F_{1,32}=1.23 \mathrm{~ns}$ & None \\
\hline $100 \%$ metamorphosed $(d)$ & nc & ne & $F_{1,32}=\overline{2.18 \mathrm{~ns}}$ & None \\
\hline $\begin{array}{l}\text { (3) Ability to delay metamorphosi } \\
\text { 1st metamorphosis (d) }\end{array}$ & $\underset{\text { sc }}{\text { sost-hatching }}$ & $\begin{array}{l}\text { ducer absent) } \\
\text { nc }\end{array}$ & $F_{1,29}=0.01 \mathrm{~ns}$ & None \\
\hline $100 \%$ metamorphosed (d) & nc & $\mathrm{nc}$ & $F_{127}=0.21 \mathrm{~ns}$ & None \\
\hline Clutch size & $F_{1,41}=\overline{0} .76 \mathrm{~ns}$ & $\begin{array}{c}y=1.68 x-249.55 \\
r^{2}=0.88 \\
F_{1,34}=225.17 \cdots\end{array}$ & $F_{1.31}=1.13 \mathrm{~ns}$ & $\begin{array}{l}\text { Larger females may } \\
\text { produce larger clutches }\end{array}$ \\
\hline
\end{tabular}


Table 4. Haminaea callidegenita. Egg size. (A) Results of a 1-way ANOVA comparing egg size (as maximum egg diameter in $\mu \mathrm{m}$ ) among 27 females. (B) Results of a linear regression of mean egg size female ${ }^{-1}(x)$ on 3 mean estimates of time of metamorphosis of her offspring (y) including: (1) intracapsular metamorphosis (\% hatching as juveniles), (2) time of competence of hatched offspring (metamorphosis completed by all siblings clutch ${ }^{-1}$ in the presence of a metamorphic inducer), (3) length of time metamorphosis can be delayed (inducer absent). $\cdots p<0.001$

\begin{tabular}{|c|c|c|c|c|c|}
\hline \multicolumn{2}{|c|}{ (A) Comparison of egg diameter among females } & \multicolumn{4}{|c|}{$\mathrm{n}=466$ eggs, $\bar{x} \pm \mathrm{SE}=262.97 \pm 0.71 \mu \mathrm{m}$} \\
\hline Source & $d f$ & SS & MS & $F$ & $\mathrm{p}$ \\
\hline Between females & 26 & 59309.53 & 2281.14 & 19.15 & $\cdots$ \\
\hline Within females & 439 & 52277.20 & 119.08 & & \\
\hline Total & 465 & 111586.74 & & & \\
\hline \multicolumn{6}{|c|}{ (B) Effects of egg size on time of metamorphosis } \\
\hline Trait & df & $F$ & $\mathrm{p}$ & $r^{2}$ & Effect \\
\hline (1) Intracapsular metamorphosis & 1,23 & 0.26 & ns & 0.01 & None \\
\hline (2) Time of competence & 1,23 & 0.64 & ns & 0.03 & None \\
\hline (3) Ability to delay metamorphosis & 1,23 & 0.17 & ns & 0.01 & None \\
\hline
\end{tabular}

females by comparing sequentially produced EM with a linear regression. Rates of intracapsular metamorphosis did not change among sequentially produced EM in 1990 and 1991, while in 1992 the percentage of juvenile hatchlings was slightly lower in masses spawned at the end of an individual's reproductive season (Table 6, $\mathrm{r}^{2}=0.07$ ). Spawning sequence did not significantly affect time of meta- morphosis of hatched larvae or their ability to delay metamorphosis (Table 6). Some reproductive traits were affected by spawning sequence, however, such as clutch size and length of the hatching period, both of which increased among sequentially produced EM (Table 6). The effect of spawn sequence on the interval between spawning events and the length of the encapsulated period was inconsistent,

Table 5. Haminaea callidegenita. Effects of source of embryos and of metamorphic inducer in determining the percentage of juvenile hatchlings. Subsamples of embryos from each egg mass (EM) were treated with egg mass jelly (EMJ) from different sources (as outlined in A), for a total of $6 \mathrm{EM}$ in the first experiment (B) and $5 \mathrm{EM}$ in the second (C). Data were analysed with a 2 -way ANOVA using arcsin transformed percentages. $\cdots p<0.001 ;$ ns: not significant

(A)

\begin{tabular}{|c|c|c|c|c|c|c|}
\hline \multirow{5}{*}{$\begin{array}{l}\text { Embryo source } \\
\text { (EMA to F) }\end{array}$} & \multicolumn{6}{|c|}{ EMJ source (EM 1 to 6$)$} \\
\hline & A. 1 & $\mathrm{~A} 2$ & A3 & A4 & A5 & A6 \\
\hline & B1 & B2 & B3 & B4 & B5 & B6 \\
\hline & $\mathrm{C} 1$ & $\mathrm{C} 2$ & $\mathrm{C} 3$ & $\mathrm{C} 4$ & C5 & C6 \\
\hline & D1 & D2 & D3 & D4 & D5 & D6 \\
\hline & E1 & $E 2$ & E3 & $\mathrm{E} 4$ & E5 & E6 \\
\hline & F1 & $\mathrm{F} 2$ & F3 & $\mathrm{F} 4$ & F5 & F6 \\
\hline
\end{tabular}

(B) March $1990 \%$ Juvenile hatchlings $\bar{x} \pm S E=54.81 \pm 3.83 \%\left(n=36, r=0.70, r^{2}=0.49\right)$

\begin{tabular}{lrrrrr} 
Source & df & SS & MS & $F$ & p \\
\hline Embryos & 5 & 1.529 & 0.306 & 4.174 & $\ldots$. \\
Metamorphic inducer & 5 & 0.235 & 0.047 & 0.642 & ns \\
Error & 25 & 1.832 & 0.073 & &
\end{tabular}

(C) July $1990 \quad \%$ Juvenile hatchlings $\bar{x} \pm \mathrm{SE}=65.67 \pm 6.12 \%\left(\mathrm{n}=20, \mathrm{r}=0.93, \mathrm{r}^{2}=0.87\right)$

\begin{tabular}{lrrrrr} 
Source & df & SS & MS & $F$ & p \\
\hline Embryos & 3 & 2.255 & 0.752 & 23.739 & $\ldots$ \\
Metamorphic inducer & 4 & 0.290 & 0.072 & 2.288 & $\mathrm{~ns}$ \\
Error & 12 & 0.380 & 0.032 & & \\
\hline
\end{tabular}


Table 6. Haminaea callidegenita. Effects of the order egg masses (EM) were spawned on reproductive traits, time of metamorphic competence and ability of larvae to delay metamorphosis in EM produced sequentially throughout the spawning period for individual females. Results are from a linear regression of effects of spawn sequence $(x)$ on each trait $(y)$. nc: data not collected. $\cdots p<0.001, \cdots p<0.01, \cdot p<0.05$

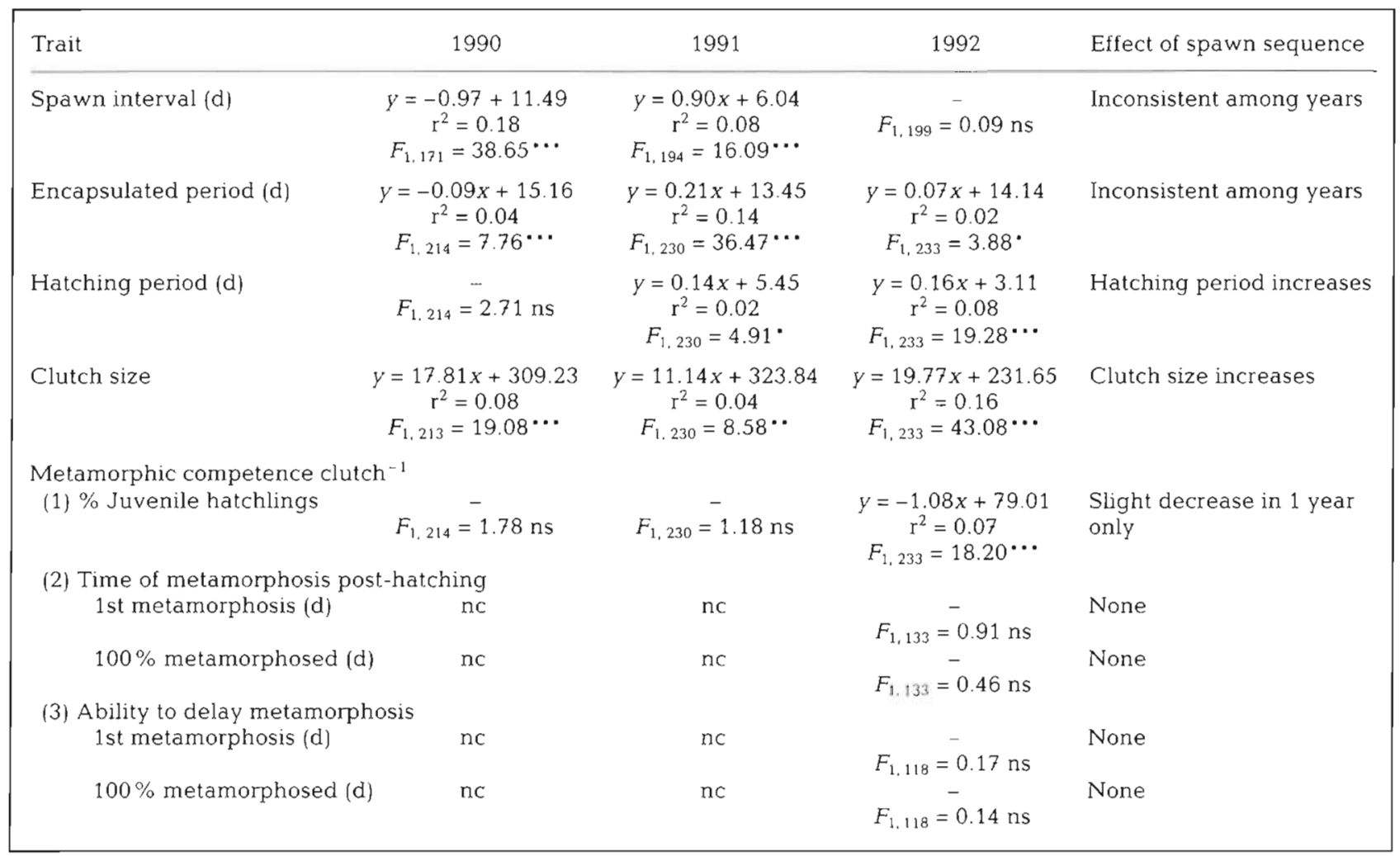

showing a general decrease in 1990 and increase in 1991.

Seasonal changes in intracapsular metamorphosis were also assessed in field-spawned EM. Rates of intracapsular metamorphosis did not show an overall trend in either year although there were differences among some months within each year (Fig. 5).

\section{Culture conditions}

EM cultured at 15 and $21^{\circ} \mathrm{C}$ released $65.8 \pm 6.4$ and $71.5 \pm 3.1 \%$ juveniles respectively (mean $\pm \mathrm{SE}$ ) but did not differ significantly (unpaired $t$-test: $\mathrm{df}=18, t=$ -0.56 ). EM cultured continuously at $9^{\circ} \mathrm{C}$ showed a high incidence of abnormal development and were discarded from the experiment.

Culture of EM in flowing seawater did not affect the percentage of juvenile hatchlings in laboratory experiments (Fig. 6, results of an unpaired 2 -tailed $t$-test: $\mathrm{df}=$ $22, t=1.08$ ). Results were similar in field experiments (Argyle lagoon; Fig. 6). Data from the field experiment were also compared with data from EM cultured with the standard culture procedure to assess the effects of laboratory culture. Again, no significant differences were found between laboratory and field cultured EM (Fig. 6, results of a 1-way ANOVA: df =2, 25, $F=0.43$ ).

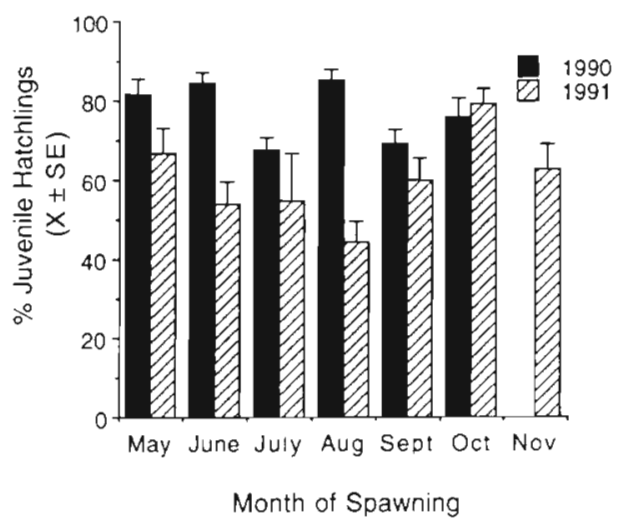

Fig. 5. Haminaea callidegenita. Seasonal changes in rates of intracapsular metamorphosis examined throughout the entire spawning season of the Padilla Bay population. Data are the mean $( \pm \mathrm{SE}$ ) percentage of juveniles hatching from egg masses (EM) coliected at monthly intervals from Padilla Bay $(n=20$

$\left.E \mathrm{M} \mathrm{mo}^{-1}\right)$ in the spawning seasons of 2 years $(1990,1991)$ 
Table 7 Haminaea callidegenita. Summary of the effects of parental environment on egg mass characteristics. Females were maintained on full-food or on half-food rations for a $40 \mathrm{~d}$ period (rations defined in text). Characteristics of each egg mass include the percentage of juvenile hatchlings (arcsin transformed before analysis), number of hatchlings and hatching period (in days). Data were compared with an unpaired 2 -tailed $t$-test. $\cdots p<0.05$; ns: not significant

\begin{tabular}{|c|c|c|c|c|c|}
\hline Trait & $\mathrm{n}$ & $\bar{x} \pm \mathrm{SE}$ & $\mathrm{df}$ & $t$ & $\mathrm{p}$ \\
\hline \multicolumn{6}{|c|}{$\%$ Juvenile hatchlings } \\
\hline Full ration & 27 & $53.34 \pm 3.09$ & 70 & -2.33 & $\cdots$ \\
\hline Half ration & 45 & $43.84 \pm 2.43$ & & & \\
\hline \multicolumn{6}{|l|}{ No. hatched } \\
\hline Full ration & 27 & $360.3 \pm 35.7$ & 70 & -0.68 & $\mathrm{~ns}$ \\
\hline Half ration & 45 & $332.6 \pm 49.6$ & & & \\
\hline \multicolumn{6}{|c|}{ Hatching period (d) } \\
\hline Full ration & 27 & $4.9 \pm 0.2$ & 70 & 0.59 & ns \\
\hline Half ration & 45 & $5.2 \pm 0.3$ & & & \\
\hline
\end{tabular}

\section{Parental environment}

Haminaea callidegenita cultured continuously in the presence of food produced a total of $27 \mathrm{EM}$, with a mean of $2.8 \pm 1.2 \mathrm{EM}$ per female (range 0 to $5 \mathrm{EM}$ ). Individuals maintained on half rations of food produced a total of 46 EM with a mean of $2.5 \pm 0.8$ EM per female (range 1 to 4 ). The percentage of juvenile hatchlings differed significantly between these 2 groups such that individuals on half-rations produced fewer juveniles overall while number of hatchlings and the length of the hatching period showed no differ-

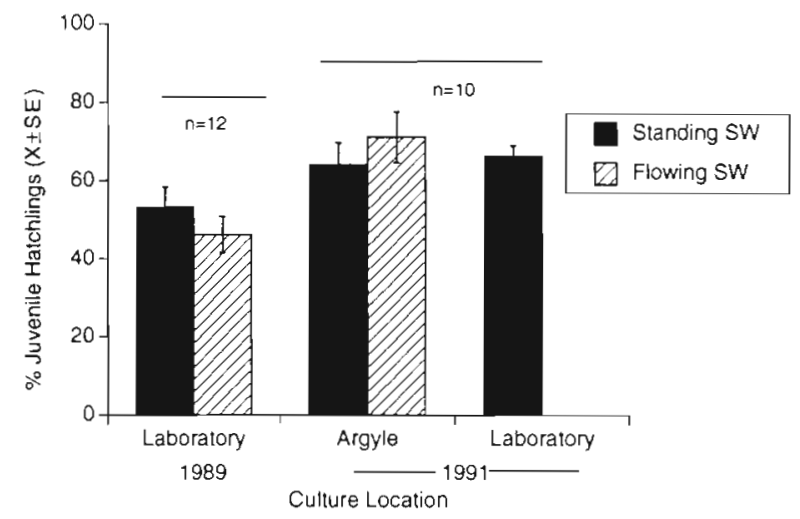

Fig. 6. Haminaea callidegenita. Effect of egg mass (EM) culture in flowing (hatched bars) or standing (solid bars) seawater on the percentage of juveniles hatching per EM. In 1989, EM were maintained in the laboratory. In 1991, EM were maintained in Argyle Lagoon (middle columns) as well as with standard laboratory techniques (column at far right; see text). Bars above columns indicate no significant differences were found within each experiment (1989, unpaired 2-tailed $t$-test; 1991, 1-way ANOVA)

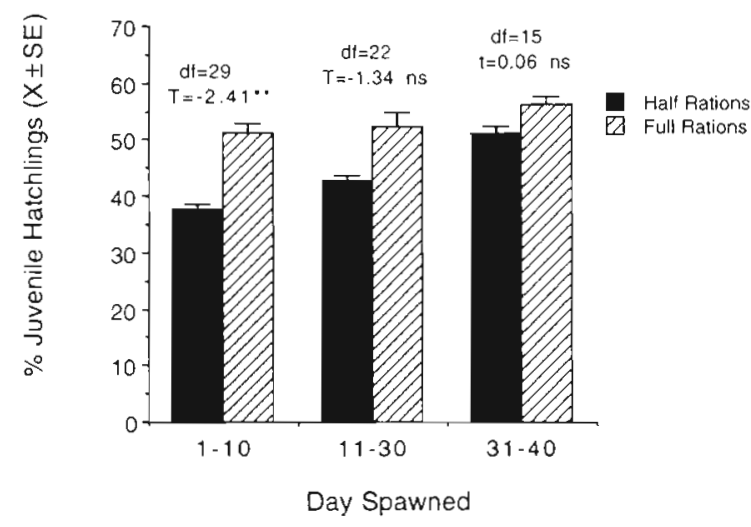

Fig. 7. Haminaea callidegenita. Effect of food availability to the parents on rates of intracapsular metamorphosis of offspring. Data are the mean $( \pm S E$ ) percentage of juveniles hatching from egg masses (EM) spawned by females continuously provided with food (full rations; hatched bars) or provided with food only on alternate days (half rations; solid bars). Comparisons were made on EM grouped by spawn date (Days 1 to 10,11 to 30 , and 31 to 40 of the experimental period) using an unpaired t-test

ences (Table 7). Females on full food rations showed no change in the percentage of juvenile hatchlings produced throughout the experimental period (Model 1 regression where $y=$ arcsin transformed \% juveniles per EM, $x=$ spawn date: $\mathrm{df}=1,26 ; F=1.03 ; \mathrm{p}>>0.05$ ) Females fed half rations showed a gradual increase in the percentage of juveniles produced (Model 1 regression: $\mathrm{df}=1,44 ; Y=0.35 \mathrm{x}+36.01 ; F=7.76, \mathrm{p}<0.01, \mathrm{r}^{2}=$ $0.15)$. The result of this increase was that females fed half rations produced significantly fewer juveniles in

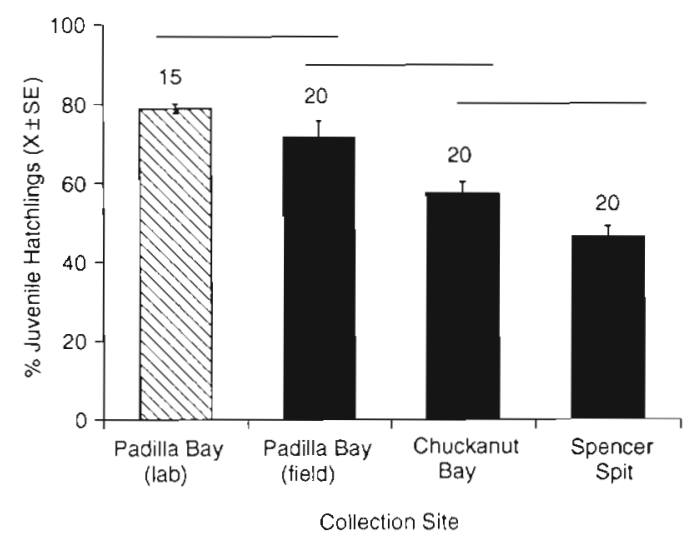

Fig. 8. Haminaea callidegenita. Percentage of juveniles hatching from egg masses (EM) collected from 3 field populations (solid bars, including Padilla Bay, Chuckanut Bay, and Spencer Spit) and from a laboratory population originally collected from Padilla Bay (hatched bar). Values are means \pm SE for each site, and sample size is indicated above each column Horizontal bars indicate no significant differences were found between indicated groups (see Table 8 ) 
Table 8. Haminaea callidegenita. Characteristics of egg masses (EM) collected from 3 field sites (P: Padilla Bay; C: Chuckanut Bay; S: Spencer Spit), as well as spawned by a laboratory population of adults originally collected from Padilla Bay. Traits considered are (1) the percentage of juvenile hatchlings $\mathrm{EM}^{-1}$ (arcsin transformed), (2) number hatched $\mathrm{EM}^{-1}$, and (3) length of the hatching period $E M^{-1}$ in days. (A) Comparison of each trait among the 3 field sites (1-way ANOVA). (B) Comparison among individual sites (Scheffé test for unplanned comparisons). (C) Comparison of the Padilla Bay field and laboratory populations (unpaired 2 -tailed $t$-test). $\cdots p<0.001, \cdots p<0.05$

\begin{tabular}{|c|c|c|c|c|c|c|c|c|}
\hline \multicolumn{9}{|c|}{ (A) Comparison among the 3 field sites } \\
\hline Trait & \multicolumn{2}{|c|}{ Source } & $\mathrm{df}$ & SS & MS & \multicolumn{2}{|c|}{$F$-ratio } & $\mathrm{p}$ \\
\hline \multirow[t]{3}{*}{ (1) \% Juvenile hatchlings } & \multicolumn{2}{|c|}{ Between sites } & 2 & 2442.10 & 1221.05 & \multicolumn{2}{|c|}{6.887} & $\cdots$ \\
\hline & \multicolumn{2}{|c|}{ Within sites } & 49 & 8687.81 & 177.3 & & & \\
\hline & \multicolumn{2}{|c|}{ Total } & 51 & 11129.91 & & & & \\
\hline \multirow[t]{3}{*}{ (2) No. hatched } & \multirow{3}{*}{\multicolumn{2}{|c|}{$\begin{array}{l}\text { Between sites } \\
\text { Within sites } \\
\text { Total }\end{array}$}} & 2 & 578398.78 & 2891.99 .38 & \multirow{3}{*}{\multicolumn{2}{|c|}{9.79}} & \multirow[t]{3}{*}{$\cdots$} \\
\hline & & & 49 & 1446460.05 & 29519.59 & & & \\
\hline & & & 51 & 2024858.82 & & & & \\
\hline \multirow{3}{*}{ (3) Hatching period (d) } & \multirow{3}{*}{\multicolumn{2}{|c|}{$\begin{array}{l}\text { Between sites } \\
\text { Within sites } \\
\text { Total }\end{array}$}} & 2 & 58.07 & 29.03 & \multirow{3}{*}{\multicolumn{2}{|c|}{7.92}} & \multirow[t]{3}{*}{$\cdots$} \\
\hline & & & 49 & 179.63 & 3.66 & & & \\
\hline & & & 51 & 237.69 & & & & \\
\hline \multicolumn{4}{|c|}{ (B) Comparison of traits among sites } & \multicolumn{5}{|c|}{ (C) Comparison between 2 Padilla Bay populations ${ }^{a}$} \\
\hline Trait & Site & Scheffé & $\mathrm{p}$ & Trait & & $\mathrm{df}$ & $t$ & $\mathrm{p}$ \\
\hline \multirow[t]{3}{*}{ (1) \% Juvenile hatchlings } & $\mathrm{P} \times \mathrm{S}$ & 6.83 & $\cdots$ & (1) \% J & nile hatchlings & 33 & -1.31 & ns \\
\hline & $\mathrm{P} \times \mathrm{C}$ & 2.67 & ns & (2) No. & ched & 33 & -0.83 & ns \\
\hline & $\mathrm{S} \times \mathrm{C}$ & 0.9 & ns & (3) Hat & Ig period (d) & 33 & 1.99 & ns \\
\hline \multirow{3}{*}{ (2) No. hatched } & $P \times S$ & 3.17 & $\therefore$ & & & & & \\
\hline & $\mathrm{P} \times \mathrm{C}$ & 1.36 & ns & ${ }^{a}$ Labord & y maintained an & ld & ted & \\
\hline & $\mathrm{S} \times \mathrm{C}$ & 9.59 & $\cdots$ & & & & & \\
\hline \multirow[t]{3}{*}{ (3) Hatching period (d) } & $\mathrm{P} \times \mathrm{S}$ & 4.59 & . & & & & & \\
\hline & $\mathrm{P} \times \mathrm{C}$ & 0.12 & ns & & & & & \\
\hline & $\mathrm{S} \times \mathrm{C}$ & 6.68 & $\cdot \cdot$ & & & & & \\
\hline
\end{tabular}

the beginning of the experimental period than did females on full rations (Fig. 7) but there were no significant differences between the offspring of the 2 groups at the end of the experimental period (Fig. 7).

\section{Inter-population differences in percentage of juvenile hatchlings}

EM collected at Padilla Bay showed the highest incidence of juvenile hatchlings and those from Spencer Spit the lowest (Fig. 8). A 1 -way ANOVA indicated significant differences among the 3 field sites overall (Table 8). The Scheffé procedure for unplanned comparisons of means (Day \& Quinn 1989) revealed significant differences in the percentage of juvenile hatchlings between Padilla Bay and Spencer Spit, geographically the most widely separated sites. EM from the Chuckanut Bay population showed proportions of juvenile hatchlings intermediate between these 2 populations, and not significantly different from either (Table 8).

EM collected from Padilla Bay were also compared with those spawned at the same time in a laboratory population of opisthobranchs originally collected from Padilla Bay. These specimens had been collected 9 mo previously and were maintained under conditions that were considerably removed from those of the natural population. An unpaired, 2 -tailed $t$-test did not reveal significant differences between these laboratory and field spawned EM (Table 8).

\section{DISCUSSION}

Poecilogony in Haminaea callidegenita occurs as a dispersal polymorphism in which every parent produces both veliger larvae and crawling juvenile offspring. This unusual development mode arises from a variable time of metamorphic competence within a clutch (spanning a $30 \mathrm{~d}$ period including pre- and posthatching periods; this study) and the presence of a metamorphic inducer (located in the EMJ) before hatching (Gibson \& Chia 1989b, 1994). The percentage of juvenile hatchlings ranged from 4 to $100 \%$ among the 800 EM observed. Other proposed cases of poecilogony involving 2 types of hatchlings have been suggested as representing benthic development with the pre-mature release of a few larval hatchlings resulting from laboratory or collection conditions (Hoagland \& Robertson 1988, Bouchet 1989). Larval development in 
H. callidegenita appears to be a true case of poecilogony because: (1) it occurs in the offspring of every individual and therefore not only involves a single species but also occurs throughout the population, (2) hatched larvae may not become competent to metamorphose until well after hatching (within 2 wk of hatching in most clutches) irrespective of food availability as these are non-feeding larvae, and (3) poecilogony does not occur as a result of some laboratory conditions which may introduce such artifacts (e.g. physical agitation due to flowing seawater).

These 2 types of hatchlings are morphologically similar as metamorphosis in this species primarily involves loss of the velar lobes, while the shell is retained throughout the juvenile and adult stages. Subsequent morphological changes from larva to juvenile occur gradually over several days after metamorphosis (Gibson \& Chia 1989b). Ecologically, however, the 2 hatchling types are very different. Swimming veligers have the potential for dispersal that would vary with onset of metamorphic competence. Crawl-away juveniles may recruit immediately to the parental population

Poecilogony in Haminaea callidegenita was not affected by larval culture conditions: culture in flowing seawater did not affect rates of intracapsular metamorphosis in either laboratory or field studies. This leads us to draw 2 conclusions. The first is that both veliger and juvenile $H$. callidegenita are released in the field, albeit under caged conditions. The second is that intracapsular metamorphosis is not affected by physical agitation of EM or by an increased oxygen concentration that may be associated with flowing seawater conditions. The second conclusion differs from observations of Carroll \& Kempf (1990) of the nudibranch Berghia verrucicornis who found that both veligers and juveniles hatch from EM if aerated during culture, but only veligers were released from EM maintained in standing cultures. The degree of intracapsular metamorphosis was also unaffected by culture temperature, although embryos cultured at $21^{\circ} \mathrm{C}$ developed more quickly and hatching began $4 \mathrm{~d}$ earlier. Embryos cultured at $9^{\circ} \mathrm{C}$ developed abnormally which suggests temperature constraints on the distribution of populations of $H$. callidegenita. This is consistent with known populations being located in bays of slightly warmer water than the surrounding open ocean (Gibson \& Chia 1991).

Poecilogony was similarly unaffected by long term adult culture, as indicated by similarities between EM spawned in the field and by a laboratory population that had been maintained under artificial conditions for at least $8 \mathrm{mo}$ prior to data collection. The lack of effect of both larval and adult culture conditions suggests that poecilogony in Haminaed callidegenita is not only quite stable but also that it is independent of at least some of the environmental parameters which may affect larval and adult stages.

The percentage of juvenile hatchlings varied almost $100 \%$ among EM. Most of this variance was accounted for by differences among clutches (50 to $90 \%)$; that is, subgroups of embryos from different EM showed rates of metamorphosis that were the same within a clutch and significantly different among clutches. This effect was independent of quantity or quality of metamorphic inducer, as well as most other potential sources of variance such as EM characteristics, as observations were made on embryos that had been completely separated from the EM. Although effects of inducer from different sources did not differ significantly, we do not eliminate the possibility that different EM contain different amounts of metamorphic inducer. However, if present these differences were not strong enough to be detected in our assays. This would not be unusual as metamorphic inducers are active in trace amounts (Pawlik 1992) and it is Iikely that inducer concentrations inside the EM would exceed such amounts.

Development time influenced the percentage of juvenile hatchlings such that EM with longer encapsulated periods released more juveniles. This relationship would be predicted as juveniles are a later ontogenetic stage. This model accounted for a small proportion $\left(r^{2} \leq 0.10\right)$ of the overall observed variance in the percentage of juvenile hatchlings but as it occurred in 2 of the study years it may be suggestive of a long term effect. The effect of length of the hatching period was less consistent among years. The contrasting effects of encapsulated and hatching periods (i.e. as occurred in 1990) suggest that high proportions of juveniles in some EM did not occur simply as an effect of a longer pre-metamorphic period.

Clutches with a high percentage of juvenile hatchlings had a shorter overall window during which metamorphic competence was reached; that is, rates of post-hatching metamorphosis were also high. These EM also showed the greatest flexibility in time of metamorphosis, as the veligers that hatched from these masses showed a slight initial increased ability to delay metamorphosis, although this ability was not maintained throughout the planktonic period. Estimates of rates of intracapsular metamorphosis and of time of competence after hatching were possibly confounded by the possibility of habituation of veligers to the inducer, because EMJ was continuously present in the culture chambers (either as intact EM or as the experimental treatment). Habituation has been observed in 2 other molluscs, Phestilla sibogae (Hadfield 1980) and Haliotis rufescens (Tradipo-Rosenthal \& Morse 1986) but was not detected in Crepidula fornicata (Pechenik \& Gee 1993). Habituation seems unlikely to affect metamorphosis in Haminaea callidegenita because 
EMJ is present throughout the entire pre-hatching larval period yet many sibs per EM will respond before hatching; also, it is not necessary to desensitize larvae before they will respond (cf. Hadfield 1980).

The percentage of juveniles hatching per EM differed between 2 populations (Padilla Bay, Spencer Spit). These population differences may reflect genetic differences as the percentage of juveniles hatching per EM is heritable (Gibson 1993). It would be interesting to test for some level of exchange of propagules between Padilla Bay and Chuckanut Bay, which would be predicted given the close proximity of the 2 sites. It is also possible that the similarity between Spencer Spit and Chuckanut Bay suggests gene flow between these sites, although a reason for lack of similar exchange with Padilla Bay is not clear. A more likely explanation is suggested by the topography of Spencer Spit, a shallow lagoon with restricted seawater exchange. The low level of intracapsular metamorphosis occurring in the Spencer Spit population could be a result of founder effects, whereby the original colonizers were planktonic larvae, and possibly were genetically 'late' to metamorphose.

Rates of intracapsular metamorphosis changed in a short term response to a 'poor' parental environment involving decreased food availability. Food-stressed females produced fewer juveniles initially, then the percentage of juveniles gradually increased to that of control conditions. In nature, this may result in females located in suddenly unpredictable or less favorable environments producing more dispersive propagules and therefore broadcasting offspring to new and possibly better habitats. The short-term nature of this response was also supported by the lack of environmental effect after maintenance of individuals in the laboratory over a long period of time. Possible mechanisms for the recovery of this response include more efficient use of resources by the adults or a return to a pre-determined threshold. Food availability may not be an ecologically valid manipulation of habitat quality as it is improbable that food would be limited in nature (Haminaea callidegenita eat diatoms and detritus, 2 sources which are abundant year round in seagrass beds, although doubtless change seasonally in composition). However, food was easily manipulated in these laboratory experiments. Quantity of food available to spawning females has been implicated in a shift in reproductive mode from lecithotrophy to planktotrophy in the nudibranch Spurilla neapolitana (Clark \& Goetzfried 1978). In contrast, food availability did not induce a shift in reproductive mode in the poecilogonous polychaetes Streblospio benedicti (Levin \& Creed 1986) and Capitella capitata (Qian \& Chia 1992), although egg size and fecundity were affected. Time of metamorphosis was not examined in these studies.
A food-induced shift in offspring type suggests a link between resource availability and development mode that may be revealed on a broader scale by an examination of reproductive energetics. However, this prediction was not supported by female reproductive traits which showed no correlation with percentage of juvenile hatchlings, whether examined as female size, fecundity, spawn interval, or total number of EM produced. The exception to this pattern was that larger clutches released fewer juveniles, but this may be a result of hatchling behavior rather than maternal investment. Early hatchlings physically disrupt the gelatinous matrix of the EM and may cause the release of more slowly developing siblings. There was no relationship between mean egg size per female and mean time of metamorphosis of her offspring (measured either as competence or the ability to delay). This observation may not accurately reflect variation in egg organic content because the relationship between egg size and organic content is intraspecifically unreliable in opisthobranchs (DeFreese \& Clark 1983), asteroids (McEdward \& Coulter 1987) and polychaetes (Bridges 1993). However, it does support the overall lack of relationship between female reproductive traits and time of competence of offspring.

Potential physical constraints imposed by EM size did not affect the percentage of juveniles released at hatching. Chaffee \& Strathmann (1984) and Strathmann \& Chaffee (1984) observed in the opisthobranch Melanochlamys diomedea that the physical size of larger EM imposes developmental constraints on embryos possibly by changing rates of oxygen or waste diffusion through the gelatinous matrix of the EM. However, the present study found that this effect, if present, did not influence hatchling type. This result is also supported by the observation that the thickness of jelly covering the eggs had no effect on hatchling type (Gibson \& Chia 1989b).

An individual Haminaea callidegenita will spawn several EM over a 6 to $8 \mathrm{wk}$ period of its year-long life. Therefore, it falls into Miller's (1962) group 1 category of opisthobranch life cycles of relatively long-lived species with a defined reproductive season (vs group 2 , characterized by opportunistic species with a short generation time and continuous reproduction). Spawn sequence showed no obvious relation to time of metamorphic competence throughout the reproductive period of individual females in 2 years, although a slight decrease in rates of intracapsular metamorphosis was observed in 1992. Other reproductive traits did differ: both clutch size and length of the hatching period increased throughout the spawning period (presumably in relation to female growth), while the interval between spawning events and length of the encapsulated period varied inconsistently among the 3 years. 
Unlike other species characteristic of Miller's Group 1, seasonal reproduction is not observed within a Haminaea callidegenita population because both reproduction and recruitment occurs throughout much of the year (Gibson \& Chia 1991). There season of oviposition had no effect on rates of intracapsular metamorphosis in EM collected from Padilla Bay. Clark et al. (1979) suggested a seasonal change in development mode may occur in Elysia subornata (nee cauze) but these observations were based on a complex of sibling species (Clark pers. comm.).

Rates of intracapsular metamorphosis, as well as other reproductive traits, differed among the 3 years studied, although the absolute differences were not all large. The most important observation from these year differences is that the effect of some traits on poecilogony also varied from year to year emphasizing the importance of studying life-history characters in more than 1 year. While the coefficients of determination for many of these regressions were small, some of these associations may have long term effects if consistent over several years (e.g. length of the encapsulated period). Inconsistent associations suggest either the role of unknown factors or combined effects of several traits (e.g. EM size, clutch size and length of the hatching period) which may influence poecilogony in different ways among years.

\section{Evolutionary implications}

In his definition of poecilogony, Giard (1905) suggested that similarity among adults may be maintained by genetics and that differentiation among offspring may arise through heterogeneous environments. A genetic basis for poecilogony in Haminaea callidegenita has been demonstrated using a half-sib analysis (Gibson 1993) which showed that the percentage of offspring hatching as juveniles is highly heritable. Environmental variability also plays a role in defining poecilogony in this species but it does so in terms of adult habitat rather than larval culture conditions. A genetic basis for poecilogony has been demonstrated in 2 other benthic marine invertebrates: the spionid polychaete Streblospio benedicti (Levin et al. 1991) and the ascoglossan opisthobranch Elysia chlorotica (West et al 1984). In both cases, development mode varies among individuals (vs among the offspring of one individual as in $H$. callidegenita); both have been successfully hybridized

The 2 processes thought to influence life-history evolution in opisthobranchs are availability of food and stability of habitat (Clark 1975). If these 2 factors are continually available direct development is frequently observed; if they are unpredictable, patchy, or ephem- eral, planktotrophy or planktonic development is common (Clark 1975, Hadfield \& Miller 1987). In Haminaea callidegenita, every individual produces both swimming larvae and crawl-away juveniles; therefore each parent produces both dispersive propagules and recruits that may settle immediately in the parental population. This development mode may be advantageous in habitats that are regionally stable but locally ephemeral, such as seagrass beds. Members of an existing population of $H$. callidegenita would have a constant supply of food as resources (diatoms and detritus) are not likely to be limiting in highly productive seagrass beds (Zieman \& Wetzel 1980) ${ }_{i}$ also, these resources are known to support a population of adults and juveniles throughout the year (Gibson \& Chia 1991). However, seagrass beds do change unpredictably from year to year through the effects of freshwater run-off and winter storms (Hartog 1987). Therefore, local conditions would favor retention of most offspring and the release of some dispersive veligers would counter the risk of local extinction.

How did this development pattern evolve in Haminaea callidegenita? Poecilogony in this species occurs because of 2 factors: a relatively long period during which metamorphic competence is reached within a clutch, and the presence of a metamorphic inducer within the egg mass. Intra-clutch variance in time of competence may be implied for larvae of a number of species (that is, metamorphosis studies in general use only the first larvae per culture that reach competence and 'slow' developers are discarded) but as these have been planktotrophic species, this observation is often attributed to differences in feeding ability. In $H$. callidegenita, this variance occurs in every EM, is not related to extrinsic food sources for the larva, and does not imply some siblings are somehow 'inferior' as all larvae do metamorphose successfully (Gibson 1993). While early recruits may have the advantage of an earlier onset of maturity, variance in time of competence (and therefore potential time of recruitment) may provide offspring with an additional element of flexibility in terms of encountering a recruitment site. Opisthobranchs are often induced to metamorphose by a juvenile or adult food source. Newly hatched $H$. callidegenita juveniles graze the surface of the EM, ingesting diatoms and possibly the jelly itself, before crawling to nearby Zostera spp. and Ulva spp., which also provide a surface from which to graze diatoms. Therefore, these 2 events (long duration of the competent period, proximity of inducer) that occur in other species of benthic marine invertebrate occur simultaneously in $H$. callidegenita, thus allowing for this unusual development mode. Poecilogony may have been retained in H. callidegenita as a 'bet-hedging' strategy (Slatkin 1974) to simultaneously allow exploitation of favorable 
local conditions as well as allow for the 'loss' of dispersive offspring as a safety net against local extinction. Although this development pattern would cause slower local rates of population increase, in may prove to be stable in the long term for the reasons of habitat unpredictability discussed above.

Acknowledgements. We thank Dennis Willows, Director, Friday Harbor Laboratories, for kindly providing us with laboratory facilities. We also thank the library at Friday Harbor Laboratories for the use of their excellent facility. The following generously permitted us access to collection sites: Doug Bulthius, Research Coordinator, Padilla Bay National Estuarine Research Reserve; Bill Dewey, Samish Bay Oyster Company; and Washington State Parks, Spencer Spit State Park This paper benefited from critical readings by L. Levin, D Padilla, J. Havenhand, J. Holmes, A. Spencer and 2 anonymous reviewers. Much thanks goes to R. Toonen for his assistance and counting expertise. This research was funded by an NSERC grant to F.S.C.

\section{LITERATURE CITED}

Bouchet P (1989) A review of paecilogony in gastropods. $\mathrm{J}$ mollusc Stud 55:67-78

Bridges TS (1993) Reproductive investment in four developmental morphs of Streblospio (Polychaeta: Spionidae). Biol Bull 184:144-152

Carroll DJ, Kempf SC (1990) Laboratory culture of the aeolid nudibranch Berghia verrucicornis (Mollusca, Opisthobranchia): Some aspects of its development and lifehistory. Biol Bull 179:243-253

Cassidy PM, McKeen GL (1986) Padilla Bay baseline water quality record Report to NOAA/OCRM/MEMD by Western Washington University, Shannon Point Marine Center, Anacortes, Washington. Padilla Bay National Estuarine Research Reserve Reprint Series No 2, 1990

Chaffee C. Strathmann RR (1984) Constraints on egg masses. I. Retarded development within thick egg masses. Biol Bull 84:73-83

Clark KB (1975) Nudibranch life cycles in the Northwest Atlantic and their relationship to fouling communities. Helgolander wiss Meeresunters 27:28-69

Clark KB, Busacca M, Stirts H (1979) Nutritional aspects of development of the ascoglossan, Elysia cauze. In: Stancyk SE (ed) Reproductive ecology of marine invertebrates Univ of S Carolina Press, Columbia, p 11-24

Clark KB, Goetzfried A (1978) Zoogeographic influences on development patterns of north Atlantic Ascoglossa and Nudibranchia, with a discussion of factors affecting egg size and number. J mollusc Stud 44:283-294

Clark KB, Jensen KR (1981) A comparison of egg size, capsule size, and development patterns in the order Ascoglossa (Sacoglossa) (Mollusca: Opisthobranchia). Int $\mathrm{J}$ Invert Repr 3:57-64

Day RW, Quinn GP (1989) Comparisons of treatments after an analysis of variance in ecology. Ecol Monogr 59(4): $4.33-463$

DeFreese DE, Clark KB (1983) Analysis of reproductive energetics of Florida Opisthobranchia (Mollusca: Gastropoda) Int J Invert Repr 6:1-10

Gianuzzi-Savelli R, Gentry A (1990) Haminaea Leach, [1820] (Mollusca, Gastropoda): proposed conservation. Bull zool Nomencl 47:263-269
Giard A (1905) La Poecilogonie. Comp Rend Six Congr Internationale de Zool Berne, 1904, p 617-646

Gibson GD (1993) Developmental variability and the induction of metamorphosis in Haminaea callidegenita (Opisthobranchia: Cephalaspidea). PhD dissertation, University of Alberta, Edmonton

Gibson GD, Chia F-S (1989a) Description of a new species of Haminoea, $H$ callidegenita (Mollusca: Opisthobranchia), with a comparison with two other Haminoea species found in the northeast Pacific. Can J Zool 67:914-922

Gibson GD, Chia F-S (1989b) Developmental variability (pelagic and benthic) in Haminoea callidegenita (Opisthobranchia: Cephalaspidea) is influenced by egg mass jelly. Biol Bull 176:103-110

Gibson GD, Chia F-S (1991) Contrasting reproductive modes in two sympatric species of Haminaea (Opisthobranchia: Cephalaspidea). J mollusc Stud 57:49-60

Gibson GD, Chia F-S (1994) A metamorphic inducer in the opisthobranch Haminaea callidegenita: partial purification and biological activity. Biol Bull 187:133-142

Gohar HAF, Eisawy AM (1967) The egg masses and development of five rachiglossan prosobranchs (from the Red Sea). Publ mar biol Stn Al-Ghardaqa 14:216-266

Hadfield MG (1980) Habituation in metamorphic induction of larvae of Phestilla sibogae (Gastropoda). Am Zool 20: 955

Hadfield MG, Miller SE (1987) On developmental patterns of opisthobranchs. Am Malac Bull 5:197-214

Hartog C Den (1987) 'Wasting disease' and other dynamic phenomena in Zostera beds. Aquat Bot 27:3-14

Highsmith RC, Emlet RB (1986) Delayed metamorphosis: effects on growth and survival of juvenile sand dollars (Echinoidea: Clypeasteroidea). Bull mar Sci 39:347-361

Hoagland E, Robertson R (1988) An assessment of poecilogony in marine invertebrates: phenomenon or fantasy? Biol Bull 174:109-125

La Barbera M (1989) Analyzing body size as a factor in ecology and evolution. A Rev Ecol Syst 20:97-117

Levin LA, Creed EL (1986) Effects of temperature and food availability on reproductive responses of Streblospio benedicti with planktotrophic or lecithotrophic development. Mar Biol 92:103-113

Levin LA, Zhu J, Creed E (1991) The genetic basis of life history characters in a polychaete exhibiting planktotrophy and lecithotrophy. Evolution 45(2):380-397

McEdward LR, Coulter LK (1987) Egg volume and energetic content and are correlated among sibling offspring of starfish: implications for life history theory. Evolution 41 $914-917$

Miller MC (1962) Annual cycles of some Manx nudibranchs, with a discussion of the problem of migration. J Anim Ecol 32:545-569

Pawlik JR (1992) Chemical ecology of the settlement of benthic marine invertebrates. Oceanogr mar Biol A Rev 30:273-335

Pechenik JA, Gee C (1993) Onset of metamorphic competence in larvae of the gastropod Crepidula fornicata (L, ) judged by a natural and an artificial cue. $J$ exp mar Biol Ecol 167:59-72

Qian P-Y, Chia F-S (1992) Effects of diet type on the demographics of Capitella sp (Annelida: Polychaeta): lecithotrophic development vs planktotrophic development. $\mathrm{J}$ exp mar Biol Ecol 157:159-179

Schmekel L, Kress A (1977) Die Gattung Doto (Gastropoda: Nudibranchia) im Mittelmeer und Armelkanal, mit Beschreibung von Doto acuta, n. sp. Malacologia 16(2) $467-499$ 
Slatkin M (1974) Hedging one's evolutionary bets. Nature 250:704-705

Sokal RR, Rohlf FJ (1981) Biometry: the principles and practice of statistics in biological research, 2 nd edn. WH Freeman \& Co, New York

Strathmann RR, Chaffee C (1984) Constraints on egg masses. I1. Effect of spacing, size and number of eggs on ventilation of embryos in jelly; adherent groups, or thin-walled capsules. Biol Bull 84:85-93

Trapido-Rosenthal HG, Morse DE (1986) Availability of

This article was presented by J. M. Lawrence (Senior

Editorial Advisor), Tampa, Florida, USA chemosensory receptors is down-regulated by habituation of larvae to a morphogenetic signal. Proc natl Acad Sci 83:7658-7662

West HH, Harrigan J, Pierce SK (1984) Hybridization of two populations of a marine opisthobranch with different developmental patterns. Veliger 26(3):199-206

Zieman JC, Wetzel RG (1980) Productivity in seagrass: methods and rates. In: Phillips RC, McRoy CP (eds) Handbook of seagrass brology: an ecosystem approach. Garland STPM Press, New York, p 87-116

Manuscript first received: May 2, 1994

Revised version accepted: January 3, 1995 